\title{
Metabolic Effects of Two Different Doses of Venlafaxine Therapy on Rats
}

\author{
Imre Annamária1 ${ }^{1}$ Kolcsár Melinda1, Groșan Alexandra1, Imre M², Dogaru Maria Titica1
}

1 Faculty of Pharmacy, University of Medicine and Pharmacy, Tîrgu Mureș, Romania

2 Faculty of Medicine, University of Medicine and Pharmacy, Tîrgu Mureș, Romania

\begin{abstract}
Objectives: Venlafaxine is an antidepressant, categorized as a serotonin-norepinephrine reuptake inhibitor (SNRI) with suspected metabolic side effects. The aim of our study was to assess these metabolic effects in rats, using two different doses of venlafaxine. Materials: Three groups of Wistar rats have been treated with venlafaxine during seven weeks. The rats have received a daily dose of $10 \mathrm{mg} / \mathrm{kg}$ (D1) and $40 \mathrm{mg} /$ $\mathrm{kg}$ (D2) while the control group (Dc) has received no treatment. Rats were given "ad libitum" access to food and water. The rats were weighted at treatment day $0,7,14,21,28,35,42$ and 49 . After completion of venlafaxine treatment, the rats were sacrificed, blood was harvested and the following biochemical parameters have been determined from the centrifuged plasma: triglycerides, glucose and total cholesterol levels. Results: Both the $10 \mathrm{mg} / \mathrm{kg}$ and the $40 \mathrm{mg} / \mathrm{kg}$ dose venlafaxine therapy resulted in a highly significant increase of rat's weight. Compared with the control group the mean weight of D1 group has increased with $130.5 \pm 21.79 \mathrm{~g}(<0.01)$ while the mean weight of the second group increased with $94 \pm 24.16 \mathrm{~g}(\mathrm{p}<0.01)$. In addition weight gain of D1 group was significantly higher than that of $D 2$ group $(p<0.01)$. Venlafaxine therapy induced significant increase in serum triglyceride levels $(140.04 \pm 55.46 \mathrm{mg} / \mathrm{dL} p<0.01,83.59 \pm 52.85 \mathrm{mg} / \mathrm{dL} p=0.05)$. This metabolic effect has been shown to be more evident in case of $10 \mathrm{mg} / \mathrm{kg}$ dose therapy ( $p=0.03$ ). Simultaneously, serum cholesterol levels have been reduced, however this decrease proved to be significant only in case of group D2 ( $p=0.03)$. Despite of increased triglyceride values, glucose levels were significantly decreased in both treated groups $(133.33 \pm 36.18 \mathrm{mg} / \mathrm{dL} p=0.05,118.10 \pm 51.98 \mathrm{mg} / \mathrm{dL} p=0.02)$. Conclusions: Our results suggest that venlafaxine administrated to rats has unwished dose related metabolic effects such as significant increase in weight and hypertriglyceridemia, however serum cholesterol and plasma glucose levels appears to be decreased by this medication.
\end{abstract}

Keywords: venlafaxine, weight, triglyceride, glucose, cholesterol

Received: 9 December 2014 / Accepted: 4 June 2015

\section{Introduction}

Weight gain is a major health problem and is a common adverse effect associated with many psychiatric drugs used to treat depression, anxiety, bipolar disorder, and schizophrenia [1]. Studies have shown that excess adiposity is a critical predictor of new onset type 2 diabetes [2,3]. The introduction of second-generation antidepressants such as venlafaxine represented an important step in the treatment of depression. The advantage of these new types of drugs consists not necessarily in their higher effectiveness, but especially in their considerably decreased risk of side effects [4]. Most of the scientific studies conducted over the past years show that these drugs are not without metabolic side effects, such as changes in body weight, insulin resistance and dyslipidemia [5]. These data related to their metabolic effects are controversial and evidence on the comparative benefits and harms is still accruing.

\section{Materials and methods}

The experiment was performed on 30 male white Wistar rats (12 months old) kept at the laboratory of the Biobase from the University of Medicine and Pharmacy Târgu Mureș. The animals weighing between 235 and $265 \mathrm{~g}$ were randomly divided in to 3 groups of 10 rats. Throughout

* Correspondence to: Kolcsár Melinda

E-mail: kolcsar.melinda@umftgm.ro the experiments the animals were maintained in the laboratory of the Biobase, under standard environment conditions (temperature $21-25 \mathrm{C}^{\circ}$, air humidity approximately $60 \%$, natural circadian cycle of day-night).

All three groups had "ad libitum" access to water and food composed mainly of proteins, fibers, vitamins and fat. The venlafaxine daily dose was calculated and weighted on an analytical balance individually for each animal. Each dose was then suspended in saline solution and administrated by gavage to each animal to ensure that all subjects received the provided dose of venlafaxine. Although the control group hasn't got medical treatment the rats were given $0.9 \%$ saline solution by gavage. The experiment lasted seven weeks during which the animals were weighed once a week.

Staggering of treatment for the three groups of animals was as follows:

Group I - control group were given $1,0 \mathrm{ml} \mathrm{0,9 \%}$ saline solution $(\mathrm{NaCl} 0.9 \%)$ without any antidepressant medication; this group received only food and water.

Group II - the animals were given $10 \mathrm{mg} / \mathrm{kgbw}$ (D1) venlafaxine administered by gavage for seven weeks.

Group III -these animals received $40 \mathrm{mg} / \mathrm{kgbw}$ (D2) venlafaxine administered by gavage for seven weeks.

Weight change monitoring of rats was carried out by weighting them with a regular basis of seven days, at the same hour, with the same balance placed in the same spot. 
The measurements were organized in tables. The weight change during every week was calculated for each rat individually, as the difference between the present weight of the rats and their initial weight measured at the beginning of the experiment. (e.g. $\Delta 1=$ weight measured on week 1 - weight measured on week $0, \Delta 2=$ weight measured on week 2- weight measured on week 0 ).

At the end of the study the rats were euthanized. Before being sacrificed the rats were anesthetized with a mixture of $100 \mathrm{mg} / \mathrm{ml}$ ketamine $0,32 \mathrm{ml} / 100 \mathrm{~g}$ bodyweight and $10 \mathrm{mg} / \mathrm{ml}$ acepromazine $0.2 \mathrm{ml} / 100 \mathrm{~g}$ bodyweight. We harvested blood for biochemical determinations and the animals were dissected. The blood was collected by intracardiac puncture in EDTA coated tubes. Serum was obtained by low-speed centrifugation of blood (10 minutes at $3000 \mathrm{RPM}$ ) and stored in a $-20^{\circ} \mathrm{C}$ freezer until analyses. We harvested perirenal and subcutaneous adipose tissue for observation.

This study was approved by the Ethics Committee of the University of Medicine and Pharmacy Târgu Mureș, România. All the procedures were designed in accordance with international and institutional guidelines for the care of laboratory animals regulated by the European Directive 2010/63/EU.

\section{Results}

Compared to the control group, which hasn't presented any significant weight change during the seven week experiment, both venlafaxine treated groups showed massive increase in body weight. The mean weight of the $10 \mathrm{mg} /$ $\mathrm{kg}$ treated group has significantly increased with 130.5 $\pm 21.79 \mathrm{~g}(\mathrm{p}<0.01)$ and the mean weight of the second group treated with $40 \mathrm{mg} / \mathrm{kg}$ dose venlafaxine increased significantly with $94 \pm 24.16 \mathrm{~g}(\mathrm{p}<0.01)$. In addition weight gain of D1 group was significantly higher than that of $\mathrm{D} 2$ group $(\mathrm{p}<0.01)$.
Rat's weight during the experiment are summarized in Table I for the control group, Table II for the D1 $(10 \mathrm{mg} /$ $\mathrm{kg}$ ) treated group and Table III for $40 \mathrm{mg} / \mathrm{kg}$ treated group.

At the end of the experiment rats were sacrificed and serum triglyceride, total cholesterol and glucose levels have been determined.

Compared to the control group which's serum triglyceride level by the end of the seven week therapy was $47.64 \pm 11.19 \mathrm{mg} / \mathrm{dL}$ the $10 \mathrm{mg} / \mathrm{kg}$ treated group induced a significant increase in triglyceride level $(140.04 \pm 55.46$ $\mathrm{mg} / \mathrm{dL} \mathrm{p}<0.01)$ and the $40 \mathrm{mg} / \mathrm{kg}$ venlafaxine therapy produced a significant increase of triglycerides ( $83.59 \pm 52.85$ $\mathrm{mg} / \mathrm{dL} \mathrm{p}=0.05$ ). This metabolic effect has been shown to be more evident in case of $10 \mathrm{mg} / \mathrm{kg}$ dose therapy ( $\mathrm{p}=0.03$ ).

Despite of increased triglyceride values, glucose levels were significantly decreased in both treated groups compared to the control group which showed $162.1 \pm 22.84 \mathrm{mg} /$ $\mathrm{dL}$ glucose $(133.33 \pm 36.18 \mathrm{mg} / \mathrm{dL} \mathrm{p}=0.05,118.10 \pm 51.98$ $\mathrm{mg} / \mathrm{dL} \mathrm{p}=0.02)$.

Simultaneously, serum cholesterol levels have been reduced, however this decrease proved to be significant only in case of group D2 $(\mathrm{p}=0.03)$. Compared to the control group which presented $82.0 \pm 21.73 \mathrm{mg} / \mathrm{dL}$ cholesterol the $40 \mathrm{mg} / \mathrm{kg}$ threated group presented $57.1 \pm 24.61 \mathrm{mg} / \mathrm{dL}$ cholesterol level.

\section{Discussions}

Preclinical studies demonstrated that the antidepressant venlafaxine selectively inhibits serotonin (5-HT) uptake at low doses, whereas at high doses, it inhibits both 5-HT and norepinephrine (NE) uptake [6]. Existing studies present controversial results regarding venlafaxine effect on weight change, however most of them suggest that this antidepressant is "weight neutral" [7]. By its mechanism of action venlafaxine enhances central serotonin and norepinephrine which both suppress appetite especially carbohy-

\section{Table I. Control group weight}

\begin{tabular}{|c|c|c|c|c|c|c|c|c|}
\hline & Initial weight & $\begin{array}{c}\text { Weight after } 1 \\
\text { week }\end{array}$ & $\begin{array}{l}\text { Weight after } 2 \\
\text { weeks }\end{array}$ & $\begin{array}{c}\text { Weight after } 3 \\
\text { weeks }\end{array}$ & $\begin{array}{c}\text { Weight after } 4 \\
\text { weeks }\end{array}$ & $\begin{array}{l}\text { Weight after } 5 \\
\text { weeks }\end{array}$ & $\begin{array}{c}\text { Weight after } 6 \\
\text { weeks }\end{array}$ & $\begin{array}{c}\text { Weight after } 7 \\
\text { weeks }\end{array}$ \\
\hline Average & 336 & 324.5 & 335 & 324.5 & 332.9 & 332.5 & 334.5 & 332 \\
\hline SD & \pm 20.92 & 21.66 & 20.41 & 21.66 & 23.21 & 19.76 & 21.01 & 19.47 \\
\hline $\mathrm{p}$ & & & & & & & & $p=0.66$ \\
\hline
\end{tabular}

Table II. $10 \mathrm{mg} / \mathrm{kgbw}$ venlafaxine treated group weight

\begin{tabular}{|c|c|c|c|c|c|c|c|c|}
\hline & Initial weight & $\begin{array}{l}\text { Weight after } 1 \\
\text { week }\end{array}$ & $\begin{array}{c}\text { Weight after } 2 \\
\text { weeks }\end{array}$ & $\begin{array}{l}\text { Weight after } 3 \\
\text { weeks }\end{array}$ & $\begin{array}{c}\text { Weight after } 4 \\
\text { weeks }\end{array}$ & $\begin{array}{l}\text { Weight after } 5 \\
\text { weeks }\end{array}$ & $\begin{array}{c}\text { Weight after } 6 \\
\text { weeks }\end{array}$ & $\begin{array}{c}\text { Weight after } 7 \\
\text { weeks }\end{array}$ \\
\hline Average & 305 & 325 & 385 & 406.5 & 403.5 & 417 & 421 & 435.5 \\
\hline SD & \pm 5.27 & 15.81 & 21.73 & 19.73 & 18.42 & 20.71 & 20.79 & 21.01 \\
\hline$p$ & & & & & & & & $p<0.01$ \\
\hline
\end{tabular}

Table III. 40mg/kgbw venlafaxine treated group weight

\begin{tabular}{|c|c|c|c|c|c|c|c|c|}
\hline & Initial weight & $\begin{array}{c}\text { Weight after } 1 \\
\text { week }\end{array}$ & $\begin{array}{c}\text { Weight after } 2 \\
\text { weeks }\end{array}$ & $\begin{array}{c}\text { Weight after } 3 \\
\text { weeks }\end{array}$ & $\begin{array}{c}\text { Weight after } 4 \\
\text { weeks }\end{array}$ & $\begin{array}{c}\text { Weight after } 5 \\
\text { weeks }\end{array}$ & $\begin{array}{c}\text { Weight after } 6 \\
\text { weeks }\end{array}$ & $\begin{array}{c}\text { Weight after } 7 \\
\text { weeks }\end{array}$ \\
\hline Average & 302 & 325 & 377.5 & 391 & 373 & 395 & 384 & 396 \\
\hline SD & \pm 4.22 & 12.69 & 20.98 & 24.70 & 35.45 & 29.53 & 31.34 & 30.26 \\
\hline $\mathrm{p}$ & & & & & & & & $p<0.01$ \\
\hline
\end{tabular}




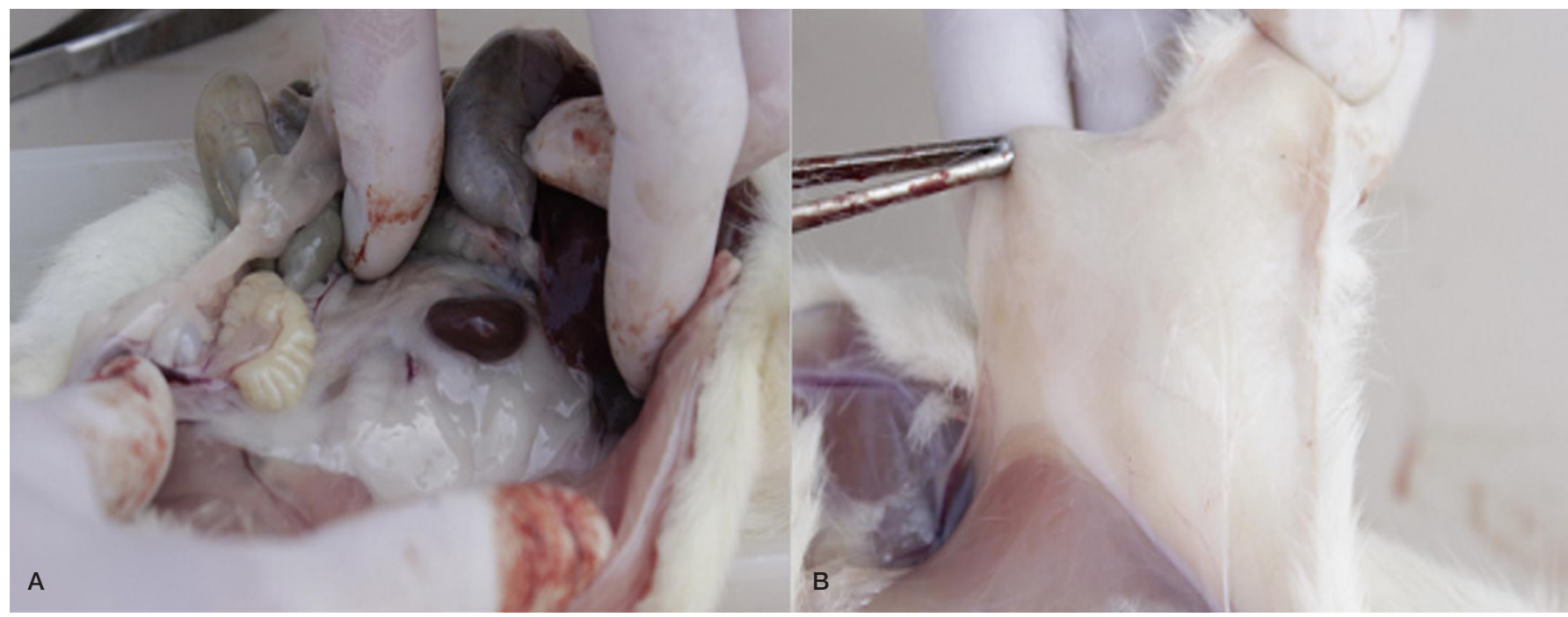

Fig. 1. A. Massive perirenal adipose tissue, B. High accumulation of subcutaneous adipose tissue (venlafaxine treated rats)

drate consumption and insulin induced hyperphagia. Our weight monitoring results on rats show us the contrary effect of this generally believes. Both threated groups had significant weight increase and in addition the lower dose therapy produced a higher level of weight gain. This apparently paradoxical effect suggests a non-neuronal pathway regulation of venlafaxine on weight.

Clinical studies showed that venlafaxine is an antidepressant which is less likely to disrupt the lipid milieu, however our result show clearly a weight related effect on lipid homestasis of the rats [8]. Both threated groups presented significant plasma triglyceride elevation and this effect was more obvious in the lower dose threated group.

During dissection all venlafaxine treated rats presented massive perivisceral and subcutaneous fat accumulation as presented in Figure 1.

Although other preclinical studies have not revealed any effect of venlafaxine on blood sugar level [9], our results present a significant decrease of blood glucose, despite of high triglyceride levels. This unexpected metabolic changes lead us to one possible explanation for the effect of venlafaxine on lipid and glucose homeostasis which means a presumptuous association between venlafaxine and peroxisome proliferator-activate receptor gamma (PPAR) nuclear receptor.

PPAR $\gamma$ promotes adipocyte differentiation in vitro and has been shown to be essential for the development of adipose tissue in vivo [10]; it plays a critical role in glucose homeostasis and is the molecular target of a class of insulin-sensitizing drugs referred to as thiazolidinediones. Activators of PPAR, including the thiazolidinediones, increase insulin sensitivity but are associated with weight gain through induction of adipogenesis [11].

Further our results regarding cholesterol level decrease under venlafaxine therapy lays in accordance with other preclinical studies which demonstrate the antiatherogenic effect of the PPAR ligands which is correlated with the increased insulin sensitivity and decreased tissue expression of TNF-alfa [12].

\section{Conclusions}

Venlafaxine administrated to rats has unwished dose related metabolic effects such as significant increase in weight and hypertriglyceridemia, however serum cholesterol and plasma glucose levels appears to be decreased by this medication.

The lack of the existing preclinical and clinical studies and the controversy of the results regarding venlafaxine's metabolic effects demands further investigations for complete understanding of venlafaxine impact on weight, glucose and lipid homeostasis. Therefore more complex investigations are needed on venlafaxine's direct effect on adipogenesis and insulin sensitizing mechanism.

\section{References}

1. Engl TJ, Laimer MS, et al. Metabolic side effects of antipsychotic medication. International Journal of Clinical Practice, 2007;61:13561370.

2. Crandall JP, Knowler WC, Kahn SK, et al. The prevention of type 2 diabetes. Nature Reviews Endocrinology, 2008;4:382-393.

3. Mclntyre RS, Soczynska JK, Konarski JZ, Kennedy SH - The effect of antidepressants on glucose homeostasis and insulin sensitivity: synthesis and mechanisms, Expert Opinion on Drug Safety, 2006;5:157-168.

4. Ferguson JM. SSRI Antidepressant Medications: Adverse Effects and Tolerability, Prim Care Companion. J Clin Psychiatry, 2001;3:22-27.

5. Masand PS, Gupta S. Long-Term side Effects of Newer-Generation Antidepressants: SSRIS, Venlafaxine, Nefazodone, Bupropion, and Mirtazapine. Annals of Clinical Psychiatry, 2002;14:175-182.

6. Harvey AT, Rudolph RL, Preskorn SH. Evidence of the Dual Mechanisms of Action of Venlafaxine, Arch Gen Psychiatry, 2000;57:503-509.

7. Kraus T, Haack M, Schuld A, Hinze-Selch D, Koethe D, Pollmächer T.

8. Body Weight, the Tumor Necrosis Factor System, and Leptin Production during Treatment with Mirtazapine or Venlafaxine. Pharmacopsychiatry, 2002;35:220-225.

9. Hummel J, Westphal S, Weber-Hamann B, Gilles M, et al. Serum lipoproteins improve after successful pharmacologic antidepressant treatment: a randomized open-label prospective trial. The Journal of Clinical Psychiatry, 2011;72:885-891.

10. Khanam R, Najfi $H$, Akhtar M, Vohora D. Evaluation of venlafaxine on glucose homeostasis and oxidative stress in diabetic mice. Hum Exp Toxicol, 2012;31:1244-50. 
11. Rosen ED, Sarraf $P$, Troy AE, et al. PPAR $\gamma$ is Required for the Differentiation of Adipose Tissue In Vivo and In Vitro, Molecular Cell, 1999;4:611-617.

12. Wasan KM, Looije NA. Emerging Pharmacological Approaches to the
Treatment of Obesity, J Pharm Pharmaceut Sci, 2005;8:259-271.

13. Li AC, Brown KK, Silvestre MJ, et al. Peroxisome proliferator-activated receptor $\gamma$ ligands inhibit development of atherosclerosis in LDL receptor-deficient mice, J Clin Invest, 2000;106:523-531. 